\title{
Fine arts foundation course teaching thinking Under the digital media technology \\ Youwei $\mathrm{Li}^{1 \text {, a }}$ \\ ${ }^{1}$ Jiangxi Institute of Fashion Technology, Jiangxi, Nanchang, 330201 \\ ${ }^{\mathrm{a}}$ email
} Keywords: Digital media technology, Colleges and universities, Clothing design, Autonomous
learning

\begin{abstract}
With the time goes on, information technology develops rapidly and also has become a essential part of our life. As the era transforms, education reform and development has been imperative too. Multimedia teaching methods could enrich the teaching patterns for basic fine art, and the application of Digital media technology could provide great convenience for teaching. The direction of education is gradually transformed into modernization, which has important significance for promoting aesthetic quality education in colleges, changing the teaching disadvantages, optimizing the teaching mode and improving the learning efficiency. Making full use of the advantages of network and arts can improve the students' knowledge as well as the teaching effect and teaching quality.
\end{abstract}

\section{Introduction}

Internet makes our life more convenient, and it has become one of the important accesses to information and communication for us. With the progress of the information age, teaching reform also needs reform. of course, the reform for art teaching is no exception. The openness of the network provides a wider space for the teaching, broadens the student's vision, provides the students with more knowledge and practical skills and helps students improve aesthetic ability and art attainment. Making full use of network, obtaining abundant education resources, developing new teaching content, exploring new teaching methods, class interaction, as well as improving the students' ability of self-analysis, understanding, imagination and creativity are all necessary. Next, analysis and practical research for the application of multimedia and Digital media technology in art teaching is given as below.

\section{Characters of Art Majors and Disadvantages in Traditional Teaching Mode}

Students of fine arts are cross the country. So the art foundations of them are very different. The art knowledge of some students is even weak. This presents difficulties for college fine art courses. For example, students learning process is difficult to master, students can't learn classes synchronously. So the enthusiasm of learning would also be affected.

In traditional art teaching, the teaching forms in painting class are usually composed by links, such as teacher's theory explanation, practical demonstration and students' practice. Such teaching model needs the combination of explanation and practice. Only by a lot of practice can the performance ability be improved step by step. Because of the limited time in classes, the time for students to understand and practice in a class is really not abundant. To achieve good teaching effect, it is important that students can take painting as a their favorite to do in addition to the certain painting knowledge of each student. Demonstration of teachers is also very important. only through demonstrating once or twice can students not record the practice for repeated revision and research. In the long term, the teaching become boring. the students' interest in learning can not be well improved. Only a few good students can keep learning. 


\section{Practical Application and Value of Multimedia Teaching in art teaching}

As one of the most widely used auxiliary means of teaching, the most typical characteristics of multimedia teaching is transforming the void abstract knowledge into visual images or videos. Information is not only rich but also fast-spreading and easy to read. Beautiful pictures, videos collected from the Internet make the teaching content enriched and the involved knowledge expanded. Multimedia teaching not only can stimulate the students' hearing and eye sight but also can benefit emotional stability and creative inspiration.

To stimulate students interest in fine arts course. In the theory explanation and art appreciation stage of basic art courses, multimedia can make the difficult content in traditional teaching vivid, clear and easy to understand. The tradition methods such as books, blackboard paintings are too limited. However, the cliff teaching model for traditional teaching has been broken by multimedia. This brand new teaching method can help students focus on study and can stimulate students' interest in art. With the help of multimedia, Passive learning can be changed into active exploration so as to produce better teaching results.

To improve the students' cultural quality and humanistic spirit. Usually, fine arts course is defined as skill courses. However, the basic art courses such as sketch and colors of art are not just skill courses. These courses also need to teach the relative theory, art expressive methods and appreciation for excellent works. As an important part of fine arts courses, the main purpose of art appreciation is improving students' cultural quality and artistic values. For example, when appreciating the work of Monet "impression, sunrise", students should be guided to analysis and understand the characteristics of the impressionists as well as the process of light and color in the painting from the painter's historical environment and cultural background. And the author's own subjective feeling should also be grasped. And then, the study for aspects such as composition, colors also have to be guided step by step guide. In this process, students can not only appreciate the art works but also can analyze and understand other artists and the background as well as spirit of works the of their works.

Basic art course can not be separated from the study of visual form and need a lot of visual resources. Visual effect affect the students' emotion and enthusiasm directly, so the effect of teaching is also affected. Teaching material collected from daily life can be introduced into computer for production. with background music, texts and graphics, teaching material can be more straightforward. Compared with pictures in books, work demonstration is clear bright and eye-catching. As a kind of aesthetic form, the beauty of multimedia course helps to create a good teaching situation, to enrich the regular education methods and to concentrate teaching organization forms. To some degree, these can stimulate students' interest in study. For example, In artistic appreciation courses, the application of multimedia make it possible to directly analyze the composition theory, the writing techniques, the picture idea, the situation and even the background of the work to achieve the real purpose of appreciation.

\section{Application of Digital media technology and its Effect Evaluation}

Through the effective application of Digital media technology, Digital media technology has been widely used in art courses. Combining with practical teaching and some multimedia teaching cases, Digital media technology has brought lots of advantages as summed up below.

Enriching Information and Improving Teaching Environment and Learning Effect. In basic art courses, one of the biggest difficulties is that students do not know what to pain. Limited by social experience, after all, the life experiences of young students are too little. Knowledge of them is also relatively narrow. Through network, information from the outside world, the related image information and art theories are easy to collect and easy to edit, store and output. In combination with the practical teaching cases, graphic with audio, teaching content can be presented obviously and directly. It provides students with more abundant material and imagination space. So it can be much easier for students to be enlightened. 
Improving Ability of Autonomous Learning and Communication for Students. Attentions are always paid when teachers preparing for classes. When preparing for classes, teachers could search on the Internet to download relative information and share these information through network communication platform. And the proper guidance for students to preview is also necessary. The process of collecting data and information can broaden students' artistic accomplishment and knowledge. Students should be guided to learn under the network environment autonomously or to cooperate by team. Therefore, the students' self-study ability can be improved. In addition, as the organizer and guider in teaching, teachers can better play a role of organization and guidance in the whole teaching process. From the perspective of students, the main purpose of multimedia teaching is to help students form good learning habits and take the initiative to learn. Besides, such a teaching method also helps supervise and urge students to think independently and encourage students talk about their new ideas after thinking. Here the online doodle board also have to be mentioned. it can record every step of the drawing by the form of animation. For example, When teacher demonstrates how to use line to draw a sketch, this tool can be used to assist in teaching. It can not only help students with learning in the classroom, but also present the detailed teaching process again after class like a tutor. At the same time, advocate cooperation and exchanges of learning also should be advocated. Constantly adjustment of the study way is also essential. However, the network information platform make it easy to realize resource sharing. Thanks to network, the teaching results and works can be shared among students, schools, provinces and even the world. It can be also easier for to find studying-partners to learn, to appreciate their art works, to share their practical experiences and so on.

Cultivating Students' Innovative Spirit and Ability of Solving Problems Alone. Application of Digital media technology in art teaching especially in the practice design class can upload the video of teaching process to network platform for sharing, which facilitate students' after-class learning a lot. Network provides extracurricular tutoring to improve teaching quality. And such a teaching form is very convenient for students to study randomly and to review. with the aid of network in appreciation courses and network platform for resources sharing, passive learning of students can be changed to active exploration so as to teach students in accordance with their aptitude. Through this communication mode, students' personality and the subjective initiative of study can be developed more fully to achieve the ideal teaching effect.

Drawing not only focuses on the enlightenment of students' art talent and inspiration of personality, but also emphasis on practical performance. The main task of the teachers is develop students' innovative ideas in right direction to put their talents in the right place. Taking the video of teaching and sharing resource with students make it possible that students can study anytime and anywhere. This not only makes up for the inconvenience of consolidate knowledge, but also help teachers to reflect and improve their teaching skills.

\section{Conclusion}

To sum up, modern computers and Digital media technology provide a wider space for art appreciation and basic art teaching. This not only make teaching information become more abundant, but also broaden students' own interests and hobbies to improve students' study enthusiasm. As a result, learning effect can also be improved gradually. In the aspect of teaching and learning, students are the leading role of learning, and teachers are major players and guiders. Therefore, under the current teaching structure, the participation of multimedia and network are of great significance for the teaching reform and development.

\section{References}

[1] Weiming Jiang, The exploration on integration of information technology with curriculum, Guangzhou, China, 1979. 
[2] Xiyong Li, Application of multimedia technology in classroom teaching of art, China Education Innovation Herald. 22 (2010) 171.

[3] Sasa Jiang, On Integrated Use of Multimedia in the Appreciation of Arts Course, Journal of Heilongjiang College of Education, 16 (2011) 90-92.

[4] Chaohui Han, Network teaching Used in the course of information technology, China Educational Technology, 9 (2001) 35-36. 